niger) root. - Phytotherapy research. 12 (7), 1998, 502-506.

10. Papi A., Orlandi M., Bartolini G., Barillari J., Iori R., Paolini M., Ferroni F., Grazia Fumo M., Pedulli G.F., Valgimigli L. Cytotoxic and antioxidant activity of 4methylthio-3-butenyl isothiocyanate from Raphanus sativus L. (Kaiware Daikon) sprouts. - Journal of agricultural and food chemistry. 56 (3), 2008, 875-883.

11. Barillari J., Cervellati R., Costa S., Guerra M.C., Speroni E., Utan A., Iori R. Antioxidant and choleretic properties of Raphanus sativus L. sprout (Kaiware Daikon) extract. - Journal of agricultural and food chemistry. 54 (26), 2006, 9773-9778.

12. Beevi S. S., Narasu M.L., Gowda B.B. Polyphenolics profile, antioxidant and radical scavenging activity of leaves and stem of Raphanus sativus L. - Plant foods for human nutrition. 65 (1), 2010, 8-17.

13. Takaya Y., Kondo Y., Furukawa T., Niwa, M. Antioxidant constituents of radish sprout (kaiware daikon), Raphanus sativus L. - Journal of agricultural and food chemistry. 51 (27), 2003, 8061-8066.

14. Vanitha Reddy P., Desai S., Ahmed F., Urooj A. Antioxidant properties and stability of Raphanus sativus extracts. - Journal of Pharmacy Research. 3 (3, Cop), 2010, 658-661.

15. Wu S., Gao Q., Zhao P., Gao Y., Xi Y., Wang X., Liang Y., Shi H., Ma, Y. Sulforaphane produces antidepressant-and anxiolytic-like effects in adult mice. $-\mathrm{Be}$ havioural brain research. 301, 2016, 55-62.

DOI 10.18699/GPB2020-47

\title{
Современное состояние генофонда рода седум (Sedum L.) в НИИСС имени М.А. Лисавенко
}

Ларина О.В., к.с.-х.н., н.с.

Федеральный Алтайский научный иентр агробиотехнологий, Барнаул, Россия e-mail:olia.sadovod@yandex.ru

В НИИСС имени М.А. Лисавенко коллекция рода Sedum L. включает 14 видов, 2 формы и 7 сортов. Представлены сведения о сроках, продолжительности иветения 23 объектов исследования в условиях лесостепной зоны Алтайского края. Перспективные образиы с высокими показателями декоративности и устойчивости рекомендованы для использования в озеленении региона.

Ключевые слова: интродукиия, седум, толстянковые, декоративность, перспективность, адаптивность.

\section{Current state of the gene pool Sedum L.} at the NIISS named after M.A. Lisavenko

Larina O.V.

Federal Altai Scientific Centre of Agro-BioTechnologies, Barnaul, Russia.

At the NIISS named after M.A. Lisavenko collection of the genus Sedum L. 
includes 14 species, 2 forms and 7 varieties. Provides information on the composition of the collection. Wintering, dates, and duration of flowering of 23 objects of researchthe in the forest-steppe zone of the Altai Territory are estimated. Promising samples with high decorative and sustainability indicators are recommended for use in landscaping the region.

Key words: introduction, sedum, Crassulaceae, decorativeness, perspective, wintering.

Алтайский край - это регион, характеризующимся суровой зимой и коротким жарким летом. Многие цветочные интродуценты не могут здесь успешно расти и цвести. Растения из рода седум (Sedum L.) - это многолетние или двулетние красивоцветущие, декоративнолиственные растения. Они перспективны для зеленого строительства из-за высокодекоративных внешних качеств, легкости размножения и высокого адаптивного потенциала $[1,2]$.

Начало работы с представителями рода седум в НИИСС имени М.А. Лисавенко положила З.И. Лучник. Ее работу продолжила И.В. Верещагина. Ею были изучены 7 видов. Из них рекомендованы для основной культуры - с. Эверса, гибридный, едкий; для выращивания с зимним укрытием - уссурийский, видный, ложный [3]. В настоящий момент генофонд рода седум в коллекции поддерживается автором статьи и по возможности пополняется новыми высокодекоративными видами и сортами.

Цель исследований: сохранение генофонда, пополнение новыми видами сортами рода седум; изучение их роста и развития, зимостойкости, декоративных качеств в условиях интродукции в лесостепи Алтайского края.

Место проведения, методика, объекты исследований. Исследования проводили в отделе «НИИСС» имени М.А. Лисавенко ФГБНУ ФАНЦА, расположенном в г. Барнауле. Город находится в лесостепной зоне Алтайского края. Климат региона резкоконтинентальный. Весной наблюдаются весенние возвраты холодов, а осенью - ранние заморозки. Посадки находятся на открытом солнечном участке без искусственного орошения.

Наблюдений проводятся по «Методике ГСИ...» для декоративных культур [4], а также методике Карписоновой [5]. Продуктивность цветения оцениваем по 5-бальной шкале, где 5 баллов - высшая, а 1 балл - низшая оценка. В статье приведены средние данные за 4 года (2016-2019 гг.).

Объекты исследований. Коллекции седумов НИИСС насчитывает 14 видов, 2 формы, 7 сортов (табл. 1). Некоторые находятся в коллекции, но наблюдения за ними на современном этапе не проводятся. Они были изучены И.В. Верещагиной, были даны рекомендации по ним [3]. Наблюдения проводятся у 6 видов, 2 форм и 7 сортов. Сорта с. видного, а также с. Эверса относятся к группе очитники (Hylotelephium), остальные - к группе очиток (Sedum). Два вида занесены в Красную книгу - с. гибридный (Красные книги 
России и Среднего Урала), с. едкий (Красная книга Мурманской области).

Таблица 1 - Генофонд рода седум в НИИСС

\begin{tabular}{|c|c|c|c|}
\hline \multicolumn{2}{|c|}{ Наблюдаемые объекты } & \multicolumn{2}{|c|}{ Место обитания вида в природе } \\
\hline 1 & 2 & 5 & 4 \\
\hline Седум белый & Sedum album $\mathrm{L}$. & $\begin{array}{l}\text { Запад. Евр., Мал. } \\
\text { Азия, Кавказ } \\
\end{array}$ & $\begin{array}{l}\text { каменистые } \\
\text { места }\end{array}$ \\
\hline $\begin{array}{l}\text { Седум видный } \\
\text { Matrona }\end{array}$ & $\begin{array}{l}\text { Hylotelephium spectabile (Bo- } \\
\text { reau) H. Ohba Matrona }\end{array}$ & \multirow{4}{*}{$\begin{array}{c}\text { северо-вост. Ки- } \\
\text { тай, Кавказ, Ки- } \\
\text { тай, Япония, } \\
\text { Монголии, Даль- } \\
\text { ний Восток, Си- } \\
\text { бирь }\end{array}$} & \multirow{4}{*}{$\begin{array}{c}\text { смешанные и } \\
\text { сосновые } \\
\text { леса, опушки, } \\
\text { луга }\end{array}$} \\
\hline $\begin{array}{l}\text { Седум видный } \\
\text { Осенняя радость }\end{array}$ & $\begin{array}{l}\text { H. spectabile (Boreau) H. } \\
\text { Ohba Autumn Joy }\end{array}$ & & \\
\hline $\begin{array}{l}\text { Седум видный } \\
\text { Red Imperator }\end{array}$ & $\begin{array}{l}\text { H. spectabile (Bor } \\
\text { Ohba Red Impe }\end{array}$ & & \\
\hline $\begin{array}{l}\text { Седум видный } \\
\text { Star Dast }\end{array}$ & $\begin{array}{l}\text { H. spectabile (Bor } \\
\text { Ohba Star D }\end{array}$ & & \\
\hline С. гибридный & Sedum hybridum L. & \multirow{2}{*}{$\begin{array}{c}\text { Сибирь, Урал, } \\
\text { Средняя Азия, } \\
\text { Монголия }\end{array}$} & \multirow{2}{*}{$\begin{array}{c}\text { степи, каме- } \\
\text { нистые } \\
\text { склоны, раз- } \\
\text { режен. леса, } \\
\text { вырубки }\end{array}$} \\
\hline $\begin{array}{c}\text { Седум гибридный } \\
\text { Xenox }\end{array}$ & Sedum hybridum L. & & \\
\hline Седул & $\mathrm{Sed}$ & $\begin{array}{c}\text { Европ. ч. России, } \\
\text { юг Сибири, Ма- } \\
\text { лая Азия, Сев. } \\
\text { Африка }\end{array}$ & $\begin{array}{c}\text { открытые } \\
\text { песчаные ме- } \\
\text { ста }\end{array}$ \\
\hline Седум испанский & Sedum hispanic & $\begin{array}{c}\text { Западная Европа, } \\
\text { Крым, Кавказ, } \\
\text { Малая Азия }\end{array}$ & $\begin{array}{l}\text { каменистые } \\
\text { склоны }\end{array}$ \\
\hline $\begin{array}{l}\text { С. камчатский с бе- } \\
\text { лой каймой }\end{array}$ & Sedum kamtschaticum Fisch. & $\begin{array}{c}\text { Дальний Восток, } \\
\text { Корея, Япония, } \\
\text { Северо-Восточ- } \\
\text { ный Китай }\end{array}$ & $\begin{array}{l}\text { каменистые } \\
\text { склоны }\end{array}$ \\
\hline Седум ложный & Sedum spirium M. Bieb. & \multirow{4}{*}{$\begin{array}{l}\text { Кавказ, Турция, } \\
\text { Иран }\end{array}$} & \multirow{4}{*}{$\begin{array}{c}\text { скальные } \\
\text { склоны, суб- } \\
\text { альпийские } \\
\text { луга }\end{array}$} \\
\hline $\begin{array}{c}\text { Седум ложный ро- } \\
\text { зовый }\end{array}$ & $\begin{array}{c}\text { Sedum spirium M. Bieb. f. } \\
\text { rosea }\end{array}$ & & \\
\hline $\begin{array}{l}\text { Седум ложный Tri- } \\
\text { color }\end{array}$ & $\begin{array}{c}\text { Sedum spirium M. Bieb. Tri- } \\
\text { color }\end{array}$ & & \\
\hline $\begin{array}{l}\text { Седум ложный } \\
\text { Roseum }\end{array}$ & $\begin{array}{l}\text { Sedum spirium M. Bieb. } \\
\text { Roseum }\end{array}$ & & \\
\hline $\begin{array}{l}\text { Седум Максимо- } \\
\text { вича }\end{array}$ & $\begin{array}{l}\text { Sedum macsimovicha (Regel) } \\
\text { S.B. Gontch. }\end{array}$ & Приморье & $\begin{array}{l}\text { скальные } \\
\text { склоны }\end{array}$ \\
\hline $\begin{array}{c}\text { Седум Мидден- } \\
\text { дорфа }\end{array}$ & $\begin{array}{l}\text { Sedum Middendorfiana } \\
\text { (Maxim.) Grulich }\end{array}$ & $\begin{array}{c}\text { Восточная Си- } \\
\text { бирь, Дальний } \\
\text { Восток, Северо- } \\
\text { Восточный Ки- } \\
\text { тай, Корея }\end{array}$ & $\begin{array}{c}\text { трещины } \\
\text { скал, щебни- } \\
\text { стые склоны, } \\
\text { скалы }\end{array}$ \\
\hline Седум отогнутый & Sedum reflexum $\mathrm{L}$. & Западная Европа & $\begin{array}{l}\text { песч. места, } \\
\text { скалы }\end{array}$ \\
\hline
\end{tabular}




\begin{tabular}{|c|c|c|c|}
\hline 1 & 2 & 3 & 4 \\
\hline Седум пурпурный & $\begin{array}{l}\text { Sedum purpureum (L.) } \\
\text { Schultes }\end{array}$ & $\begin{array}{l}\text { Европа, Сибирь, } \\
\text { Дальний Восток }\end{array}$ & $\begin{array}{c}\text { каменистые и } \\
\text { глинистые } \\
\text { почвы }\end{array}$ \\
\hline Седум тоненький & Sedum tenellum M. Bieb. & $\begin{array}{l}\text { Кавказ, Иран, } \\
\text { Турция }\end{array}$ & $\begin{array}{c}\text { щебнистые } \\
\text { скалы, каме- } \\
\text { нистые места } \\
\end{array}$ \\
\hline $\begin{array}{c}\text { Седум } \\
\text { шестигранный }\end{array}$ & Sedum sexangulare L. & Западная Европа & $\begin{array}{c}\text { сухие песча- } \\
\text { ные, камени- } \\
\text { стые почвы }\end{array}$ \\
\hline Седум Эверса & $\begin{array}{l}\text { Hylotelephium Ewersii } \\
\text { (Ledeb.) H. Ohba }\end{array}$ & $\begin{array}{c}\text { Юг Сиб., Алтай, } \\
\text { Ср. Азия, Сев. } \\
\text { Индия, Монго- } \\
\text { лия, Зап. Китай }\end{array}$ & $\begin{array}{c}\text { галечники, } \\
\text { прирусл. } \\
\text { пески кам. } \\
\text { склоны, }\end{array}$ \\
\hline
\end{tabular}

Результаты. Род седум (Sedum L.) относится к семейству Толстянковые (Crassulaceae DC.) и насчитывает от 280 до 650 видов (в зависимости от классификации), распространенных главным образом в умеренных и горных районах Северного полушария. Седумы в коллекции НИИСС разнообразны по своим характеристикам. По окраске листьев выделены группы: с зеленой окраской листвы (3 сорта с. видного, гибридный, едкий, испанский, Максимовича, Миддендорфа, отогнутый, тоненький, шестигранный); с пурпурной (видный Matrona, пурпурный); с сизой (Эверса); с пестрой (камчатский, ложный Tricolor).

Отрастание большинства седумов проходит в II половине апреля (табл. 2). Сорта с. видного Matrona и Star Dast отрастают в мае. Через 10-15 дней после отрастания седумы уже обладают декоративным эффектом. Больше половины образцов (57 \%) - это растения, зацветающие в июне. Цветение начинается с середины июня. Наиболее раннее цветение у с. Миддендорфа - 14.06. Седум ложный Tricolor относиться к среднему сроку цветения - 04.07. Остальные виды и сорта относятся к позднему сроку цветения. Начало зацветания у них приходится на август - сентябрь. Наиболее позднее цветение у с. гибридного Star Dast - 25.09 (табл. 2).

Большинство образцов (12) имеют высокий балл (4-5) и длительный период цветения (от 27 до 47 дней), что говорит об их успешной интродукции (табл. 2). Особенно выделяются следующие образцы, имеющие высокий балл и длительную продолжительность цветения: седум видный Осенняя радость, с. видный Matrona, с. камчатский, с. ложный белый, с. ложный Roseum. Седум гибридный Xenox, сорта с. видного Red Imperator и Star Dast проявляют плохую адаптацию в условиях лесостепной зоны Алтайского края; имеют низкий балл продуктивности (1-2) и короткую продолжительность (7-15 дней) цветения.

В коллекции имеются образцы с белыми, желтыми, розовыми и пурпурными цветами (табл. 2). 
Таблица 2 - Характеристика объектов исследований, среднее 2014-2019 гг.

\begin{tabular}{|c|c|c|c|c|c|}
\hline \multirow{2}{*}{ Объекты исследований } & \multicolumn{2}{|c|}{ Начало } & \multirow{2}{*}{ 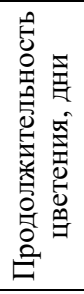 } & \multirow{2}{*}{ 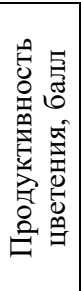 } & \multirow{2}{*}{$\begin{array}{l}\text { Окраска } \\
\text { цветков }\end{array}$} \\
\hline & отрастания & цветения & & & \\
\hline Седум гибридный Xenox & 25.04 & $*$ & - & - & - \\
\hline Седум видный Осенняя радость & 29.04 & 24.08 & 45 & 5 & розовая \\
\hline Седум видный Matrona & 05.05 & 28.08 & 42 & 4 & розовая \\
\hline Седум видный Red Imperator & 28.04 & 26.08 & 15 & 1 & пурпурная \\
\hline Седум видный Star Dast & 03.05 & 25.09 & 7 & 2 & белая \\
\hline Седум испанский & 20.04 & 07.06 & 47 & 3 & желтая \\
\hline Седум камчатский & 22.04 & 27.06 & 40 & 4 & желтая \\
\hline Седум ложный белый & 17.04 & 28.06 & 37 & 5 & белая \\
\hline Седум ложный розовый & 22.04 & 26.06 & 29 & 5 & розовая \\
\hline Седум ложный Roseum & 19.04 & 30.06 & 41 & 5 & пурпурная \\
\hline Седум ложный Tricolor & 24.04 & 04.07 & 35 & 3 & розовая \\
\hline Седум Максимовича & 20.04 & 16.06 & 29 & 5 & желтая \\
\hline Седум Миддендорфа & 19.04 & 14.06 & 26 & 5 & желтая \\
\hline Седум пурпуровый & 30.04 & 09.08 & 40 & 4 & пурпурная \\
\hline Седум шестигранный & 22.04 & 21.06 & 33 & 4 & желтая \\
\hline
\end{tabular}

* - не имел цветения во все годы исследований

Выводы. Генофонд рода седум в НИИСС составляет 14 видов, 2 формы и 7 сортов. Имеющиеся в коллекции образцы разнообразны по фенологическим и биометрическим параметрам (окраска цветков, габитус куста, форма листьев, время цветения). Большинство из них (12) имеют высокие показатели адаптивности (зимостойкость, разрастание кустов, регулярное цветение), декоративности в условиях интродукции. Особенно выделены седум видный Осенняя радость, с. видный Matrona, с. камчатский, с. ложный белый, с. ложный Roseum. Седум гибридный Хеnox, сорта с. видного Red Imperator и Star Dast показывают низкую адаптацию.

\section{Список литературь}

1. Касынкина О.М. Возможности использования селена для декоративных особенностей очитка // Аграрная наука - сельскому: сборник материалов XIII Международной научно-практической конференции: в 2 кн. (15-16 февраля 2018 г) ФГБОУ ВО «Алтайский государственный аграрный университет». - 2018. - С. 47-48. 
2. Орлова О.Н., Сорокопудова О.А. Виды очитковых (Crassulaceae) для озеленения города Белгорода / Научные ведомости Белгородского государственного университета. - Серия: Естественные науки. - 2010. - Т. 9. - С. 45-48.

3. Верещагина И.В., Долганова 3.В. Зимующие многолетники, рекомендуемые для Алтайского края. Методические рекомендации. / Сиб. отд-ние ВАСХНИЛ, НИИСС. - Новосибирск. - 1985. - 36 с.

4. Методика государственного испытания сельскохозяйственных культур: Декоративные культуры. - М.: Колос, 1968. - Вып 6. - 223 с.

5. Карписонова Р.А. Травянистые растения широколиственных лесов. - М.: «Наука», 1985. - С. 56-62.

\section{Изменчивость шишек и семян клонов сосны кедровой сибирской (Pinus sibirica Du Tour) в Краснообске}

Лихенко Н.Н.*, к.с.-х.н., в.н.с.; Чудная А.П., агроном 1 категории; Капко Т.Н., м.н.с.

Сибирский научно-исследовательский институт растениеводства и селекиии - филиал ИЦиГ СО РАН, Новосибирск, Россия.

*e-mail: lihenko.n@yandex.ru

Приведены данные, характеризующие размеры шишек и семян клонов плюсовых деревьев сосны кедровой сибирской, произрастающих на территории дендропарка СибНИИРС - филиала ИЦиГ СО РАН. По совокупности признаков клонов выделился № 96, поскольку на нем формировались наиболее крупные и полнозернистые шишки с наибольшим выходом семян по массе (19,9 г) и массе 1000 семян (256,7 г).

Ключевые слова: сосна кедровая сибирская, клон, иишка.

\section{Variability of cones and seeds at clones of Siberian cedar pine in Krasnoobsk}

Likhenko N.N. *, Chudnaya A.P., Kapko T.N.

SibRIPP\&B - branch ICG SB RAS, Novosibirsk, Russia.

*e-mail: lihenko.n@yandex.ru

The data characterizing the sizes of cones and seeds of clones of plus trees of Siberian cedar pine, which are grows in the arboretum of SibRIPP\&B-branch ICG SB RAS, are provided. According to the totality of features, clone No. 96 stood out. It formed the largest and most full-grain cones with the highest seed yield by weight (19.9 g) and 1000 seeds $(256.7 \mathrm{~g})$.

Key words: Siberian cedar pine, clone, cone.

Сосна кедровая сибирская - это одна из наиболее значимых в хозяйственном отношении орехоплодных хвойных пород, представляющей интерес в качестве источника ценной древесины и продуктов пищевого и технического 